\title{
A Comparative Study of Intracervical Instillation of PGE2 Gel (O.5mg) Versus Vaginal Tab PGE1 $(600 \mu \mathrm{g})$ for Second Trimester MTP
}

\author{
Dr. Shipra Agarwal ${ }^{1}$, Dr. Saral Bhatia ${ }^{2}$ \\ ${ }^{1} 3^{\text {rd }}$ Year Resident, Department of Obst \& Gyne \\ ${ }^{2}$ Associate Professor, Department of Obst \& Gyne
}

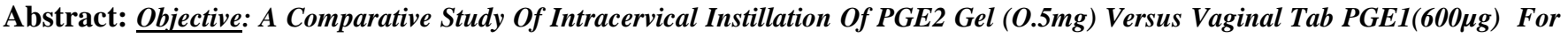
Second Trimester MTP. Material and Methods: The study was undertaken in the department of Obstetrics and Gynecology at New Civil Hospital, Surat from March 2015-November 2015. Sixty consenting women willing for 2nd trimester MTP coming to New Civil Hospital Surat were randomly divided in two groups. Group A (30 subjects) induction was done with intracervical instillation of $0.5 \mathrm{mg} P G E 2$ gel

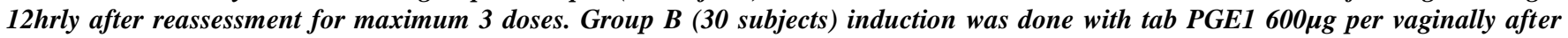
reassessment every 6 hrly upto maximum 4 doses. Result: Mean age of subjects was 24years in Group A(PGE2) and 23.9 years in Group $B(P G E 1)$. Most of the subjects enrolled for second trimester MTP were having pregnancy between 14-16weeks.The mean drug instillation of group $A$ was 2.1 times while in group B was 2.9 times which was statistically significant.The mean induction abortion interval in group A was 21.5hours and that of group B was 15.4 hours which was statistically significant. The success rate of group A was $93.3 \%$ while that of group B was $96.6 \%$ The difference in final outcome was statistically not significant. Conclusion: Second trimester termination of pregnancy using PGE1 (Misoprostol) was found safe and effective with shorter induction abortion interval . Compared to other drugs available for second trimester MTP PGE1(Misoprostol) is cost effective, can be stored at room temperature, lesser side effects and complications and with higher success rate.
\end{abstract}

Keywords: MTP, second trimester, Misoprostol, PGE1

\section{Introduction}

India pioneered in legalizing induced abortion (Medical Termination of Pregnancy (MTP) Act of 1971) under which a woman can legally avail abortion if the pregnancy carries the risk of grave physical injury, endangers her mental health, or results from a contraceptive failure in a married woman or from rape or is likely to result in the birth of a child with physical or mental abnormalities.

According to the MTP act, abortion is permitted up to 20 weeks of pregnancy duration and no spousal consent is required.

Though second trimester abortions account for a small percentage of all induced abortions, it is associated with high rate of morbidity.

Two thirds of major abortion related complications and half of abortion related mortality occur in pregnancies terminated after 13 weeks of gestation ${ }^{1}$.

$\mathrm{PGE}_{1}$ (Misoprostol) has emerged as a critical component of these regimens both as a stand-alone method and in combination with other medications like Mifepristone ${ }^{2}$. It is widely used because it is inexpensive and stable at room temperature. It can be absorbed via oral, vaginal, sublingual, buccal and rectal routes. Many clinical trials have found vaginal administration to be more effective than oral administration $^{3}$.

The naturally occurring prostaglandin $E_{2}$ is known as Dinoprostone. It has important effects in labour (softening the cervix and causing uterine contraction). It is available as vaginal insert, vaginal suppositories, cervical gel.
Therefore we conducted the study to compare the efficacy of vaginal $\mathrm{PGE}_{1} \mathrm{tab}$ (Misoprostol) with intracervical instillation of $\mathrm{PGE}_{2}$ gel (Dinoprostone) in second trimester MTP $(\geq 12$ and $\leq 20$ weeks).

\section{Aims \& Objectives:}

1) To compare the induction abortion interval in $\mathrm{PGE}_{2}$ induced group versus $\mathrm{PGE}_{1}$ induced group.

2) To compare the side effects of $\mathrm{PGE}_{2}$ versus $\mathrm{PGE}_{1}$ induced group.

3) To compare the complications of $\mathrm{PGE}_{2}$ versus $\mathrm{PGE}_{1}$ induced group.

\section{Material and Methods}

The study was undertaken in the department of Obstetrics and Gynecology at New Civil Hospital, Surat from March 2015-November 2015. Sixty consenting women willing for $2^{\text {nd }}$ trimester MTP coming to New Civil Hospital Surat were randomly divided in two groups. Group A (30 subjects) induction was done with intracervical instillation of $0.5 \mathrm{mg}$ $\mathrm{PGE}_{2}$ gel $12 \mathrm{hrly}$ after reassessment for maximum 3 doses. Group B (30 subjects) induction was done with tab PGE1 $600 \mu \mathrm{g}$ per vaginally after reassessment every 6 hrlyupto maximum 4 doses.

\section{Inclusion Criteria:}

1) Pregnant woman coming for $2^{\text {nd }}$ trimester MTP between gestational age of 14 to 20 weeks.

2) Those patients who understood the medical regimen and gave informed written consent for induction with regimen. 


\section{International Journal of Science and Research (IJSR) \\ ISSN (Online): 2319-7064 \\ Index Copernicus Value (2013): 6.14 | Impact Factor (2015): 6.391}

\section{Exclusion Criteria}

1) Contradictions to (PGE1): Mitral Stenosis, Glaucoma, Sickle Cell Disease, Severe Asthma, K/C/O allergy to Prostaglandins.

2) Contradiction to (PGE2): Asthma, Glaucoma, Pulmonary Disease, Hepatic Disease, k/c/o allergy to prostaglandins.

3) Previous 2 or more L.S.C.S.

4) Past H/O Classical C.S.

5) Past history of rupture uterus/myomectomy.

6) Woman who did not give consent.

Detailed history, examination and conselling were done. Eligible candidates were explained about the two arms of the study. After enrollment, gestational age was estimated by last menstrual period, clinical examination and USG. Randomization was done.

Routine investigations necessary prior to MTP i.e. Hb estimation, blood grouping, urine albumin sugar were done in all subjects. Written informed consent was taken.

The subjects were monitored for onset of pains, uterine contractions and bleeding. Pelvic examination was performed every 6 hrly before the next dose.

Induction abortion interval was defined as time period between first dose to the expulsion of products of conception. The primary outcome measure was the success rate at $30 \mathrm{hr}$ of first instillation. Success was defined as the expulsion of products of conception whether complete or incomplete within 30 hrs of the first dose.If abortion did not occur within this time limit then it was considered as "failure".In the event of failure ,pre consent was taken that termination of pregnancy would be done by surgical methods(hysterotomy) or mechanical dilatation of cervix with oxytocin infusion.

\section{Observations and Discussion}

\begin{tabular}{|c|c|c|}
\hline Epidemiological factor & $\begin{array}{c}\text { Group-A(PGE } \\
(\mathrm{n}=30)\end{array}$ & $\begin{array}{c}\text { Group-B(PGE } \\
(\mathrm{n}=30)\end{array}$ \\
\hline Mean age(years) & 24 & $23.9 y r s$ \\
\hline Meangestational age(weeks) & 17.2 & 17 \\
\hline
\end{tabular}

\begin{tabular}{|c|c|c|c|c|c|}
\hline & $\begin{array}{c}\text { Dose of } \\
\mathrm{PGE}_{2} \text { gel }\end{array}$ & $\begin{array}{c}\text { Group } \\
\mathrm{A}\end{array}$ & $\begin{array}{c}\text { Dose of } \\
\mathrm{PGE}_{1} \text { tab }\end{array}$ & $\begin{array}{c}\text { Group } \\
\mathrm{B}\end{array}$ & P value \\
\hline Once & $0.5 \mathrm{mg}$ & 01 & $600 \mu \mathrm{g}$ & 01 & $<0.5$ \\
\hline $\mathbf{2}$ times & $1.0 \mathrm{mg}$ & 25 & $1200 \mu \mathrm{g}$ & 05 & $<0.001$ \\
\hline $\mathbf{3}$ times & $1.5 \mathrm{mg}$ & 04 & $1800 \mu \mathrm{g}$ & 20 & $<0.001$ \\
\hline $\mathbf{4}$ times & & & $2400 \mu \mathrm{g}$ & 04 & - \\
\hline
\end{tabular}

- Mean drug instillation of group A was 2.1 times while in group $\mathrm{B}$ was 2.9 times which was statistically significant $(\mathrm{P}=0.0001)$ (unpaired Ttest)

\begin{tabular}{|c|c|c|c|c|c|}
\hline $\begin{array}{c}\text { Induction abortion } \\
\text { Interval[hours] }\end{array}$ & \multicolumn{2}{|c|}{$\begin{array}{c}\text { Group-A } \\
(\mathrm{n}=28 / 30)\end{array}$} & \multicolumn{2}{c|}{$\begin{array}{c}\text { Group-B } \\
(\mathrm{n}=29 / 30)\end{array}$} & P value \\
\hline$<6$ & 0 & $0 \%$ & 1 & $3.3 \%$ & - \\
\hline $6-12$ & 1 & $3.3 \%$ & 5 & $16.6 \%$ & 0.22 \\
\hline $13-18$ & 5 & $16.6 \%$ & 20 & $66.6 \%$ & 0.29 \\
\hline $19-24$ & 20 & $66.6 \%$ & 2 & $6.6 \%$ & 0.39 \\
\hline $24-30$ & 2 & $6.6 \%$ & 1 & $3.3 \%$ & 0.19 \\
\hline Failure(>30) & 2 & $6.6 \%$ & 1 & $3.3 \%$ & \\
\hline Mean (in hours) & $21.5 \mathrm{hr}$ & - & $15.4 \mathrm{hr}$ & - & $<0.0001$ \\
\hline
\end{tabular}

- Majority of subjects (67\%) in group A delivered between 19-24 hours, whereas majority of subjects (67\%) in group B delivered between 13-18 hours, which is more important for emotional wellbeing of patient.

(As shorter induction delivery interval reduce the chances of emotional trauma to the patient). Subjects delivered within 12 hours in group A were 1 out of 30 (3\%) while the same in group B were 5 out of $30(17 \%)$.

Comparision of mean IAI between different studies

\begin{tabular}{|c|c|c|}
\hline & \multicolumn{2}{|c|}{$\begin{array}{c}\text { Induction } \\
\text { Interval }\end{array}$} \\
\hline & $\mathrm{PGE}_{2}$ & $\mathrm{PGE}_{1}$ \\
\hline PRESENT & $21.5 \mathrm{hr}$ & $15.4 \mathrm{hr}$ \\
\hline JAIN \&MISHELL(1994) & $10.6 \mathrm{hr}$ & $12 \mathrm{hr}$ \\
\hline M.KHOOSHIDEH(2007) & $15.1 \mathrm{hr}$ & $13.2 \mathrm{hr}$ \\
\hline
\end{tabular}

Mean induction abortion interval in $\mathrm{PGE}_{2}$ is 21.5hr and $\mathrm{PGE}_{1}$ is $15.4 \mathrm{hr}$ which was statistically significant $(\mathrm{P}<0.0001)$ (unpaired T-test). However in Jain and Mishell $^{4}$ et al 1994 and M.Khooshideh ${ }^{5}$ et al 2007,the induction abortion interval in $\mathrm{PGE}_{2}$ and $\mathrm{PGE}_{1}$ were nearly similar and statiscally not significant

\begin{tabular}{|c|c|c|c|c|}
\hline Final Outcome & \multicolumn{2}{|c|}{$\begin{array}{c}\text { Group A(PGE } \\
(n=30)\end{array}$} & $\begin{array}{c}\text { Group B(PGE } \\
(n=30)\end{array}$ \\
\hline Successful & 28 & $93.3 \%$ & 29 & $96.6 \%$ \\
\hline Failure & 2 & $6.6 \%$ & 1 & $3.3 \%$ \\
\hline
\end{tabular}

- The success rate of group A was 93.3\% while that of group B was $96.6 \%$ The difference in final outcome was statistically not significant (Chi-square test).

- The failure rate of group A was $6.6 \%$ while that of group B was $3.3 \%$.

\begin{tabular}{|c|c|c|}
\hline Side effects & $\begin{array}{c}\text { Group A } \\
\left(P G E_{2}\right)\end{array}$ & $\begin{array}{c}\text { Group B } \\
\left(P G E_{1}\right)\end{array}$ \\
\hline Nausea & 5 & 7 \\
\hline Vomiting & 2 & 4 \\
\hline Fever & 4 & 2 \\
\hline Need for analgesics & 3 & 1 \\
\hline Shivering & 4 & 6 \\
\hline Headache & 1 & 0 \\
\hline Total no. of patients & 15 & 12 \\
\hline
\end{tabular}

- The above table shows the relation of side effects between two groups $50 \%$ and $40 \%$ subjects in group $\mathrm{A}\left(\mathrm{PGE}_{2}\right)$ and group $\mathrm{B}\left(\mathrm{PGE}_{1}\right)$ respectively had side effects.

- The common side effects in both groups ware nausea,shivering, fever and vomiting .

\begin{tabular}{|c|c|c|}
\hline Complication & $\begin{array}{c}\text { Group A } \\
\left(\mathrm{PGE}_{2}\right)\end{array}$ & $\begin{array}{c}\text { Group B } \\
\left(\mathrm{PGE}_{1}\right)\end{array}$ \\
\hline Hemorrhage & 02 & 0 \\
\hline Shock & 0 & 0 \\
\hline Hypertonic Uterine contraction & 0 & 0 \\
\hline Uterine Rupture & 0 & 0 \\
\hline
\end{tabular}

2 subjects in group A had hemorrhage, while in group B no subject had complication. This complication was due to prolong induction abortion interval and this was controlled by oxytocics only without any need for blood transfusion or other surgical interventions. 


\section{Conclusions}

Second trimester pregnancy termination is still a complicated procedure in developing countries especially in rural areas. There is constant search going on for an ideal method which is $100 \%$ reliable, safe and cheap.

Second trimester termination of pregnancy using $\mathrm{PGE}_{1}$ (Misoprostol) was found safe and effective with shorter induction abortion interval .

Compared to other drugs available for second trimester MTP PGE1 (Misoprostol) is cost effective, can be stored at room temperature ,lesser side effects and complications and with higher success rate.

\section{References}

[1] World health organization Medical Methods Of Termination of Pregnancy, World Health Organization , geneva 1997,871

[2] Borgatta L, Kapp N. Labor induction abortion in the second trimester. Contraception. 2011;84(1):4-18.

[3] Ashok PW, Flett GM, Templeton A. Termination of pregnancy at 9-13 weeks amenorrhoea with mifepristone and misoprostol. Lancet. 1998;352:542-3.

[4] John K.Jain ,And Daniel R. Mishell, in 1994comparision study of intravaginal Misoprostol with PGE2 for second trimester termination of pregnancy.N.Engl.J.Med,331:290-293.

[5] M. Khooshideh , 2007. The Comparison of Misoprostol and Dinoprostone for Termination of Second Trimester Pregnancy. Journal of Medical Sciences, 7: 289-293. 